\title{
Investigating the Possibility and Effects of Arbitration Term in the Statute of Commercial Firms
}

\section{Investigación de la posibilidad y los efectos del plazo de arbitraje en el estatuto de las empresas comerciales}

\author{
HamidReza Afarin \\ M.Sc. Student of Private Law, Mashhad Branch, Islamic Azad University, Mashhad, Iran \\ ORCID: https://orcid.org/0000-0001-6176-618X

\section{Rasool Maghsoodpoor} \\ Assistant Professor, Department of Law, Mashhad Branch, Islamic Azad University of \\ Mashhad, Mashhad, Iran \\ ORCID: https://orcid.org/0000-0002-2949-0838
}

Received 02-08-20 Revised 04-10-20

*Correspondence

Email: R.maghsoodpoor@gmail.com

\section{Cite as:}

Afarin, H.R., \& Maghsoodpoor, R. (2021). Investigating the Possibility and Effects of Arbitration Term in the Statute of Commercial Firms. Propósitos y Representaciones, 9 (SPE1), e875. Doi: http://dx.doi.org/10.20511/pyr2021.v9nSPE1.875

(C) Universidad San Ignacio de Loyola, Vicerrectorado de Investigación, 2021. 


\section{Summary}

Arbitration is carried out based on the parties' agreement, outside official authorities. As a result, it is carried out faster, at a lower price, and based on the confidence of the both parties in the arbitrator(s). The ways to include arbitration term in the statute of commercial firms include stating in the contract, stating in the statute, and stating in other commercial documents such as articles of partnership and primary corporation agreement. The conditions of validity of including arbitration term in the statute of commercial firms are the same as essential trading terms pointed to in the article 190 of the civil code. Cases in which including the arbitration term in the statute of commercial firms is prohibited include bankruptcy related disputes, which based on the article 496 of the civil procedure code (2001) cannot be settled through arbitration. This is because bankruptcy is a matter of public order. In addition, there are doubts whether arbitration term can be included in the statute of commercial firms in cases of certain disputes such as termination, nullity and in general, company-dissolution-disputes. This is also because in terms of effects, company dissolution is similar to bankruptcy, leaving the task of determining a settlement manager to the court instead of arbitrators.

Keywords: Arbitration term, statute, commercial firm, article 190 of the civil code, bankruptcy

\section{Resumen}

El arbitraje se lleva a cabo sobre la base del acuerdo de las partes, fuera de las autoridades oficiales. Como resultado, se lleva a cabo más rápido, a un precio menor y en base a la confianza de ambas partes en el árbitro o árbitros. Las formas de incluir el término de arbitraje en el estatuto de las firmas comerciales incluyen declarar en el contrato, declarar en el estatuto y declarar en otros documentos comerciales, tales como artículos de asociación y acuerdo de corporación primaria. Las condiciones de validez de la inclusión del término arbitral en el estatuto de las sociedades mercantiles son las mismas que las condiciones comerciales esenciales señaladas en el artículo 190 del código civil. Los casos en los que se prohíbe la inclusión del término arbitral en el estatuto de las empresas comerciales incluyen disputas relacionadas con la quiebra, que con base en el artículo 496 del código de procedimiento civil (2001) no pueden resolverse mediante arbitraje. Esto se debe a que la quiebra es una cuestión de orden público. Además, existen dudas sobre si el plazo de arbitraje puede incluirse en el estatuto de las sociedades mercantiles en casos de determinadas disputas como terminación, nulidad y en general, disputas-disolución-societaria. Esto también se debe a que, en términos de efectos, la disolución de la empresa es similar a la quiebra, dejando la tarea de determinar un administrador de liquidación al tribunal en lugar de a los árbitros.

Palabras clave: Plazo de arbitraje, estatuto, empresa mercantil, artículo 190 del código civil, concurso de acreedores.

\section{Introduction}

Arbitration term or condition is a contract term. The subject of arbitration term is in fact an obligation, and a commitment. According to the arbitration term, the parties to a contract will 
be committed to refer their future disputes to arbitrators. By the arbitration term, all parties to a contract are obliged to refer to an arbitrator in case of occurrence of any dispute.

There are two traditionally well-known ways to include the arbitration term for commercial firms. One way is to include arbitration term in the signed contracts, and the other is to include the term in companies' statute. However, in some other cases the arbitration term could be stated in other commercial documents such as articles of partnership, or the corporation's primary agreement. In order to better explain the issue, the mentioned methods will be discussed in the following to clarify the subject of including arbitration term in the statute of commercial firms.

Regarding stating the arbitration term in the signed contracts it can be stated that:

The parties to the contract agree while signing the contract to refer to arbitration references in case of occurrence of any dispute. Iranian laws clearly accept the arbitration term (Shams, 2010, p512).

When the parties mention the arbitration term in the main contract form, the arbitration term will become a constituent of the main contract form, therefore becomes an obligation for the parties. This subject is of great importance, especially in terms of jurisprudence; in a way that many jurists believe that such agreements will only be obligatory if they are mentioned in the main contract, but if they are agreed upon separately, they would be considered as primary terms, hence would not be obligatory.

Regarding stating the arbitration term in the statute, it is worthy of mentioning that in the law of commerce, the legislator has remained silent in this regard, having made no references to it. However, since there is no legal prohibition in this context, according to the principles, all disputes can be referred to arbitrators unless for cases in which it is legally prohibited.

In the present study it has been firstly tried to investigate the possibility of including arbitration term in the statute of commercial firms, and secondly to analyze the effects of doing so. In the other parts of the research, those cases will be stressed out in which, including the arbitration term is whether prohibited or doubted. In addition, the cons and pros of including the arbitration term in the statute of commercial firms will be investigated as well.

\section{Methodology}

The present study is a descriptive analytic study. Therefore, in order to carry out the study, first library studies have been conducted and articles and content related to the subject matter have been investigated. In addition, through referring to authentic internet databases, the articles related to the subject matter have been identified and studied. In the following, the contents will be analyzed and evaluated.

\section{$1^{\text {st }}$ Topic: Investigating the Research Concepts}

\section{$1^{\text {st }}$ Word: The Concept of Arbitration}

In vocabulary, arbitration means to judge for disputes between people, or ruling people (Moein, 2002, p1492). 
In expressions, arbitration involves taking disputes privately to certain individuals instead of courts, to reach a resolution in a shorter time and without having to go through the specific protocols of courts (Sadr Afshar, 1995, v3, p410).

\section{$1^{\text {st }}$ Paragraph: The Lexical Definition of Arbitration}

In terms of vocabulary, an arbitrator is a judge who settles disputes among people (Moein, 2004, $\mathrm{v}-2, \mathrm{p}-1063)$. It is also referred to those who do not have any judicial post in the state, but work on potential or in-effect disputes and settle them through their verdicts (Jafari Langroodi, 2008, v3, p6889).

\section{$2^{\text {nd }}$ Paragraph: The Legal Definition of Arbitration}

In terms of legal expressions, arbitration is defined as settling or resolving a dispute by one or more individuals, instead of the judges of the official state courts (Previous, p283).

In another definition we have: resolution of disputes between people, outside state courts, by individual(s) selected by the parties (Shams, 2008, v3, p515).

\section{$2^{\text {nd }}$ Word: Arbitration Term}

In terms of concept, arbitration term in contracts is considered as a commitment, and an obligation. It obliges the parties to the contract to settle any future occurring disputes through arbitration. On this basis, it can be summarily stated that the article of arbitration in contracts means that the parties are committed to refer their future disputes to arbitrators, instead of taking their disputes to state courts. Resultantly, the definition of arbitration term is not the same as the definition of arbitration.

The title of arbitration terms is normally referred to an alternative contract commitment, implying that future disputes must be settled through arbitration.

The effects of arbitration term include commitment and obligation to take disputes to arbitrators. As a result, such commitment can be stated in the contract. Therefore, referring a dispute to arbitration process is possible as a contract condition, and such terms are principally functions of the main contract (Salimi et al., 2018, p77).

\section{$3^{\text {rd }}$ Word: Including the Arbitration Term in the Contract}

When the parties to a contract include the arbitration term in the main contract form, the arbitration term becomes a constituent of the main contract, therefore becoming an obligatory commitment. This subject is of great importance, especially in terms of jurisprudence; in a way that many jurists believe that such agreements will only be obligatory if they are mentioned in the main contract, but if they are agreed upon separately, they would be considered as primary terms, hence would not be obligatory (Shiravi, 2015, p94).

In this regard, this question has been raised whether the arbitration term has an independent nature, or it depends on the main contract and nullity of the contract results in termination of the term?

The article 461 of the civil procedure code states: whenever there is a dispute or disagreement about the main contract and arbitration term, the state court will have to investigate the case and 
issue a verdict.

On this basis, in the civil procedure code, the validity or nullity of the arbitration term would be function of the main contract. This is why in the article 461 of the civil procedure code the arbitrators have not been allowed to comment on the validity or nullity of the main contract, leaving it to the state court. In fact, once the state issues a verdict regarding the validity or nullity of the contract, the arbitrators can intervene.

However, the s1 of the article 16 of the international commercial arbitration law maintains: the arbitrator can comment on his/her competence and existence or validity of an arbitration agreement. When the arbitration term is a constituent of the contract, in terms of this law, the agreement is viewed as an independent one. If the arbitrator decides that the contract of interest is null and ineffective, it would not mean that the arbitration term mentioned in the contract is also null.

\section{$4^{\text {th }}$ Word: The Lexical and Legal Definitions of Statute}

In terms of vocabulary, statute means a piece of text or document that declares the most principal topics of a subject. In the business law, statute is a document containing the most crucial topics related to a corporation, approved by the founders. The possibility to alter the statute of corporations has been anticipated by the legal act of 1969 (Ansari \& Taheri, 2006, v1, p41). Statutes contain rules and regulations for handling a corporation's affairs (Hasani, 2007, v5, p41).

\section{$5^{\text {th }}$ Word: Variations of Arbitration and its Characteristics}

\section{$1^{\text {st }}$ Paragraph: Variations of Arbitration}

Types of arbitration include optional and compulsory, which have been explained in the following.

\section{A) Optional Arbitration}

By optional arbitration it is meant that the sides can either state in the main contract or set an alternative agreement implying that in case of occurrence of a dispute, an arbitrator will be selected and the dispute will be settled according to the verdict of the arbitrator. This has been stressed out in the articles 632 and 633 of the civil procedure code.

\section{B) Compulsory Arbitration}

There are cases where the court decides that with respect to the present conditions and situations, the dispute must be referred to arbitration for resolution. This is termed as compulsory arbitration, since the sides of the dispute have no part in determining whether to refer to arbitration or not.

\section{$6^{\text {th }}$ Word: Characteristics of an Arbitrator, the Manner of Determining an Arbitrator, and Benefits of Arbitration}

$1^{\text {st }}$ Paragraph: Cases of Deprivation from Arbitration and Compensation 
According to the article 473 of the civil procedure code, in case of the following counts arbitrators will not be allowed to take part in arbitration cases for up to five years:

1- Absence in arbitration sessions without a justified excuse

2- Quitting without a justified excuse

3- Refusing to issue a verdict

Not only the mentioned cases will prohibit the arbitrators from arbitration, but also inflicting damages on either side of the contract results in holding the arbitrator responsible to compensate for the damages. According to the article 501 of the civil procedure code, whenever by fraud, cheating or negligence of the arbitrators, financial damages are inflicted, they would be held accountable. This shows that non-material damages do not require compensation by arbitrators.

\section{$2^{\text {nd }}$ Paragraph: The Restrictions of Arbitrator Selection According to the Articles 466, 469, and, 470 of the Civil Procedure Code (2001)}

in case of disputes, the sides can take their case to arbitration under the following conditions:

1- The sides are qualified to file a complaint

2- The sides agree to take their case to arbitration

\section{$3^{\text {rd }}$ Paragraph: Benefits of Arbitration}

Settling or resolving disputes through arbitration has the following benefits:

1) Saving Time; for investigating the cases and issuing verdicts, the arbitrators are not bound by the regulations of the procedure code, and so always try to resolve disputes in shortest times possible while investigating cases in courts takes long times.

2) Saving Money; those who want to sue must pay the due costs of procedure, this is while arbitrators usually do not charge the sides and settle their disputes to help the sides. Except in certain cases of heavy work, in which the wages of the arbitrators must be paid by the sides, unless another the contract entails another arrangement for paying the wages.

3) Selecting a Trusted Judge; selecting the arbitrator is principally done by the sides of the dispute, and they will try to select a trusted person, whereas in courts the judges are not appointed by the sides of the dispute, and so the judge may not be trusted by the sides.

4) Inward Benefit; since the arbitrator is selected and appointed by the sides and they have more confident in their selection, the arbitrator too will try for closure between the sides, which will create a relative commonality between them. This is ethically important since it cannot be expected from the court (Sadr Afshar, 1373, p411).

\section{$2^{\text {nd }}$ Topic: Investigating the Possibility of Including the Arbitration Term, and its Effects}

\section{$1^{\text {st }}$ Word: Investigating the Possibility of Including the Arbitration Term in Firms' Statute, and the Resulting Restrictions}

The legislator of Iran has remained silent regarding the possibility of including the arbitration term in the statute of commercial firms, and therefore there is no legal prohibition in this regard. In addition, the business law (1932) in certain cases such as the article 108, states that for Limited Liability Companies the relations between the partners are functions of the statute.

So, regarding including the arbitration term in the statute of LLCs, it can be stated that: 
With respect to the nature of the statute and its acceptance by the partners and stakeholders, the arbitration term is considered as a constituent of collective agreement and it must be adhered to. Anticipating the term in the statute, is a bilateral act similar to including the term in the contract, and it must be abided.

On this basis, if the statute of an LLC states that the disputes between the associates or partners must be resolved through arbitration, whether a specific individual has been selected as the arbitrator or not, the associates are obliged and committed to take their case to arbitration if it was not resolved through negotiation.

For instance, if the statute of an LLC states that "the associates agree to settle their disputes through arbitration", it means that none of the associates of an LLC can independently refer to state courts to settle their disputes; rather the dispute must be firstly referred to arbitration for resolving.

In addition, it is noteworthy that as long as no one has referred to arbitration, taking the case to a state court will not be legally acceptable, and so the court cannot intervene in the case.

Regarding the inclusion of the arbitration term in the statute of private held companies, in the part 5 of the statute dedicated to the board of directors and its authorities, it can be stated that:

For any measure in the name of the company, and or any operation and deal relating to the subject of the company for which the general assemblies are not competent to make a decision, the board of directors has unlimited authority. More specifically, regarding the inclusion of the arbitration term, it can be stated that the board of directors will have unlimited authority regarding signing contracts including an arbitration term, referring disputes to arbitration and selecting an arbitrator, executing the arbitrator's verdict, requesting an executive order for prosecution, and prosecution of the defendants.

\section{For Public Companies, the Arbitration Term is Included in the following way:}

The article 2 of the code of arbitration in the public sector (2001) states that the sides of the dispute who have been obliged to resolve the dispute through arbitration due to the statute, must abide to the existing regulations and take their dispute case to arbitration references whether it has been already taken to a court or not; and if no such thing was maintained by the statute, they can agree on taking their case to arbitration. In the remark of the article 1 it has been mentioned that settling criminal disputes is not bound to this regulation. In addition, settling the disputes between the members or the non-member stakeholders of public held companies with each other or third parties will not be subjected to this regulation, unless the sides agree to.

Nevertheless, according to the amendments of certain articles of the public sector law of the I.R.I (2015), it has been maintained by the remark 6 of the article 57 that it is obligatory to include the arbitration term in the statute of such companies.

Therefore, it can be stated that except for public held companies for which it is an obligation to include the arbitration term in the statute, for other company types, the disputes must be referred to arbitration only when the term of arbitration has been included in the statute of the corporation by the will of the founding associates; otherwise, there will be no obligation.

$2^{\text {nd }}$ Word: Investigating the Ways to Include the Arbitration Term in the Statute of Commercial Firms 
Regarding stating the arbitration term in the statute of commercial firms, it is worthy of mentioning that in the law of commerce, the legislator has remained silent in this regard, having made no references to it. However, since there is no legal prohibition in this context, according to the principles, all disputes can be referred to arbitrators unless for cases in which it is legally prohibited.

However, one of the most important features of arbitration term is that such agreements are included when there is no dispute, and it is not known for sure that there will be one in the future (Shams, 2010, p512).

\section{$3^{\text {rd }}$ Word: Including the Arbitration Term in other Corporate Documents}

It is possible to include arbitration in the articles of partnership or the primary agreements of firms. To this end, it would also be necessary to investigate these counts as well.

\section{$1^{\text {st }}$ Paragraph: Including the Arbitration Term in the Articles of Partnership}

Regarding the inclusion of the arbitration term in the articles of partnership, the legislator has not commented on the points that must be contained by the articles of partnership. However, in the law of business and in cases related to forming LLCs, in some cases the term "articles of partnership" has been mentioned as a main element in forming a corporation. According to the article 197 of the law of business, the mentioned corporations must hand the summary of articles of partnership to the ministry of justice during the first month of existence of the company.

\section{$2^{\text {nd }}$ Paragraph: Including the Arbitration Term in the Primary Corporate Agreement}

Similar to the articles of partnership, it is also possible to include the arbitration term in the primary corporate agreement as well. This document is meant for forming a corporation and is arranged by the primary founders. But again, the legislator has remained silent regarding the points to include in this document. However, practically the document prepared and published by the Companies Registration Office is used.

\section{$4^{\text {th }}$ Word: Investigating the Cases of Compulsory Inclusion of the Arbitration Term in the Statute of Commercial Firms}

The remark 6 of the article 57 of the law of amendment of certain articles of the law of public economy of I.R.I (2014) maintains that including the arbitration term in the statute of public held companies is compulsory. Also the article 76 of the mentioned law, obliges the public held corporations to amend their statutes. In fact, all public held corporations have been obliged to include the term in their statutes in no longer than 3 months after the issuance of the mentioned law; otherwise, the corporations will no longer be viewed as public held ones, and so cannot use the benefits of public held companies.

The remark 6 of the article 57 of the mentioned law maintains:

Reference to the arbitration must be included in the statute of all public held companies. As a guarantee to execute this law, the legislator of Iran states in the article 76 of the law of amendments of certain articles of the public economy law of I.R.I: all public held corporations have been obliged to include the term in their statutes in no longer than 3 months after the issuance of the mentioned law; otherwise, the corporations will no longer be viewed as public 
held ones, and so cannot use the benefits of public held companies.

\section{$5^{\text {th }}$ Word: Investigating the Conditions for Inclusion of the Arbitration Term in the Statute} of Commercial Firms

\section{$1^{\text {st }}$ Paragraph: Investigating the conditions of article 190 of the civil code regarding contracts}

The main conditions and terms of dealing according to the article 190 of the civil code are as follows:

1- Intention and consent of the sides

2- Qualification of the sides

3- the subject of the deal must be determined

4- the legitimacy of the deal

\section{$2^{\text {nd }}$ Paragraph: Investigating the Conditions for Realization of Arbitration}

By contractual arbitration term it is referred to the fact that the parties to a specific contract, state in the contract document and oblige themselves to refer to arbitration references in case of occurrence of any dispute (Shams, 2010, v3, p507). The conditions for realization of arbitration are the same as general conditions for realization of contracts. In this regard, all conditions envisaged by the article 190 of the civil code for contracts, also apply to arbitration.

Arbitration is a code based on the consent and agreement of the sides to a dispute, and this consent will be mentioned in the arbitration contract document. By arbitration contract, it also referred to arbitration term, since the term itself is a contract based on the consent and agreement of the sides, but only mentioned in a separate contract by the will of the parties (Katoozian, 2013, v3, p167).

The arbitration term is a contract recognized by the article 10 of the civil code, and just like any other contract, it must be adhered to (Dashti \& Karimi, 2014, p102).

The article 472 of the civil procedure code justifies the principle of necessity of contracts, as well as the objectives of referring to arbitration (Katoozian, 2013, p254).

An arbitration agreement can be signed by those who are qualified to sue. In addition to the s2 of the article 190 of the civil code, the article 454 of the civil procedure code states regarding qualification: anyone with the quality to sue or file a complaint, can agree upon taking their case to an arbitration reference, no matter whether the case has been already brought to a state court or not.

$6^{\text {th }}$ Word: Investigating the Cases in which Inclusion of the Arbitration Term in the Statute of Commercial Firms is Totally Prohibited

The article 496 of the civil procedure code (2001) states: the following disputes cannot be referred to arbitration:

1- Bankruptcy disputes 2- etc.

\section{$1^{\text {st }}$ Paragraph: Investigating Bankruptcy Related Disputes}


In vocabulary, bankruptcy means desperation of business, and in terms of commerce, it is considered as a halt in payments. In the other words, by bankruptcy it is referred to inability of legal or real business-owners to make their payments. The article 412 of the business law states regarding bankruptcy:

Bankruptcy has taken place when the merchant is no longer able to make the necessary and required payments. On this basis, in Iranian Law, bankruptcy is exclusive to merchants (Ansari Moein, 2009, p257).

\section{A) Investigating the necessity of issuance of bankruptcy verdict by the court:}

The article 415 of the business law states that bankruptcy must be verified by a court verdict; however, currently a qualified district court is in charge of issuing bankruptcy verdicts. When a corporation or merchant declares bankruptcy, then a plea must be made for all or some of the creditors. It means that in the designated column, the bankrupt entity must mention the names of all or some of the creditors, with one creditor's address who is determined by the court. In addition, when a creditor sues a company for bankruptcy, the residence and address of the defendant determines which qualified court should deal with the case. The main condition for declaring bankruptcy is the inability of the company or merchant to make their payments.

\section{B) Investigating the reasons why bankruptcy disputes cannot be referred to arbitration:}

Bankruptcy is associated with public order. This characteristic not only keeps such disputes from being referred to arbitration and requires the intervention of state courts, but also allows the attorney general to intervene with the process of managing the merchant's or the corporation's properties; an active intervention specified by certain legal articles, and with respect to social evolutions, rational interpretation of the authorities of the attorney general, and considering for important objectives such as prevention of occurrence or continuance of disputes it must be reviewed.

The business law points to some of the most important authorities of the attorney general as follows:

Supervising the listing of properties, selling the properties, paying the debts to creditors, sealing the properties, conducting the operation of deduction of account balance, selling the bale, and access to the documents of the bankrupted entity, and plea for credit restoration. These authorities question the necessity of intervention of the attorney general in bankruptcy cases. How can we put so many tasks on the shoulders of the attorney general, but still count him/her as an outsider in the mentioned disputes? In addition, these authorities must be stressed out for certain legal entities, because the level of bankruptcy and the practical effects of the bankruptcy are so extensive that if no active intervention is made by the attorney general, the society will be exposed to threats of deep crises (Khodabakhshi, 2014, pp13-14).

However, it is also worthy of mentioning that principally bankruptcy disputes cannot be referred to arbitration, because as mentioned, this is an issue of public importance. But, personal disputes and bankruptcy related demands can be referred to arbitration just like any other type of dispute (Eskandari, 2006, p37).

$2^{\text {nd }}$ Paragraph: Investigating the Cases of Doubt and the Associated Reasons in terms of 


\section{Inclusion of Arbitration Term in Commercial Firms' Statute}

In the views of a handful of lawyers, the inclusion of the arbitration term in the statute of commercial firms is doubted in the face of certain disputes. These lawyers maintain that disputes of termination, nullity, and in general, corporation dissolution disputes are amongst the former.

The reasons for the doubts include the following:

a) In terms of effects, the dissolution of a company is similar to its bankruptcy, and based on the reasons stated for bankruptcy, the cases of corporations' dissolution cannot be referred to arbitration.

b) Arbitration is time bound, meaning that the arbitrator cannot issue his/her verdict outside a specific time length. However, company dissolution requires a six-month time length, leaving the arbitrators unable to cover it even by extending their time, unless the sides have agreed upon the accessories to the arbitration while anticipating it in their contract; even if the requirement is granting a six-month time.

c) Dissolution disputes cover the entirety of the legal entity, or at least one of its' publiclyeffective decisions, and leaves an effect on the stakeholders and third parties. Since it has already been made clear that arbitration is effective only for disputes between parties.

$3^{\text {rd }}$ Topic: Investigating the Effects of Inclusion of Arbitration Term in the Statute of Commercial Firms

\section{$1^{\text {st }}$ Word: Investigating the limits of court intervention in case of existence of arbitration term in the statute of commercial firms}

What if even though the arbitration term has been anticipated in the statute of commercial firms, the plaintiff refers to a court instead of taking his/her case to an arbitrator? In the other words, would existence of arbitration term in the statute of commercial firms deprive the parties of the right to refer to state courts in case of occurrence of disputes and force them to refer to arbitration? And would it also apply to the next buyers of the stocks who will be considered as the deputies of the primary stakeholders? The next question that rises is what would be the extent or limits of the intervention of the court if possible? There are two general theories regarding this issue, which are both explained in the following.

\section{$2^{\text {nd }}$ Word: Inclusion of arbitration term in the statute and the possibility of referring to courts, and the limits of court intervention}

In the French law, based on the parts 2 and 3 of the article 1458 of the civil procedure code, involvement of state courts in disputes subject to arbitration would only be prohibited if the qualification of the state courts is denied. However, if the arbitration agreement is nulled, the court would not accept the denial.

The Iranian civil procedure code does not provide a specific answer to this question. But it can be said that even death, resignation, and etc. of the arbitrator would not impede the process of arbitration; leaving it to the court to determine a replacement for the arbitrator. On the other hand, courts have been rendered as qualified to involve with disputes subject to arbitration in certain cases (Shams, p540).

\section{$1^{\text {st }}$ Paragraph: Intervention of the court prior to arbitration}


By court intervention prior to arbitration, it is referred to measures the court is allowed to, and in some cases obliged to take prior to the initiation of arbitration. Court intervention prior to initiation of arbitration, starts when one of the parties claims that the term of arbitration is either nonexistent or null according to certain legal reasons once the dispute has been referred to arbitration (Pavic, 2010, p134).

\section{$2^{\text {nd }}$ Paragraph: intervention of court during arbitration}

The question that rises now is whether the court can intervene if the arbitrator is already working the dispute?

The Iranian civil procedure code also lacks a specific answer to this question; however based on the article 491 of the civil procedure code, the answer to the former question must be no. the s2 of the article 84 and the article 89 of the mentioned code also do not support this solution. However, in the French Law, declaring the court as unqualified is conditioned to adduction (Shams, Previous; p542).

\section{$3^{\text {rd }}$ Paragraph: Court intervention post to issuance of arbitration verdict}

According to the article 490 of the civil procedure code, the parties to the contract can plea for nullification of the arbitration verdict from the court that referred the dispute to arbitration, or a qualified court within 20 days from issuance of the arbitration verdict. On this basis, one of the domains of court intervention after or post to the issuance of arbitration verdict, can be considered as handling the objections made to the arbitrators' verdicts, while the other one relates to execution of the arbitrators' verdicts. The defendants usually execute the arbitrators' verdicts optionally. The legislator has given the defendant a 20-days to 2-months' time to optionally execute the arbitration verdict.

\section{$3^{\text {rd }}$ Word: Inclusion of the arbitration term in the statute and impossibility of referring to state courts}

According to other views, the dominant view of the laws of different countries and international conventions hold that when there exists an arbitration contract, the courts would not be qualified to handle the case, and must refuse to judge the dispute by referring it to arbitration (Moslehi \& Sadeqi, 2007, p91).

The article 8 of the international arbitration law envisages that the court to which the case of the subject of arbitration has been brought to, must refer the case to arbitration by the end of the court session, unless it is made clear that the agreement of arbitration is either null or ineffective. Taking the dispute to the court will not stop the process of arbitration.

According to this content, the article 8 of the mentioned law maintains that when an arbitration contract is signed, the courts will no longer be qualified to intervene, and if the contract of arbitration is signed before the occurrence of dispute, the courts will be deprived of the ability obtain competence for intervention (Kaviani, 2002, p132).

According to this perspective, in case of existence of arbitration term, taking the dispute case to a state court will be in contrast to the principle of rule of will in contracts, and the essence of the 
article 10 of the civil code as well (Zandi, 2015, p119).

According to the above mentioned content and the related laws is it clear that in disputes of interest, a special place has been considered for anticipation of arbitration in the statute of commercial firms, putting the arbitration references in higher priorities compared to judicial authorities. Resultantly, to settle the disputes individuals will have to refer to arbitrators, while being able to take the dispute to state courts if the arbitrators refuse to handle the case due to legal reasons (Akhavan, 2013, p20).

\section{Conclusion}

Arbitration term is a contractual condition. The subject of arbitration term, is in fact a commitment, and an obligation. According to the arbitration term, the parties will be committed to refer their future disputes to arbitration. Both parties will be obliged against each other to take the case to arbitration in case of occurrence of a dispute in the future.

In the remark 6 of the article 57, the legislator obliges public held companies to refer disputes to arbitration, and anticipates a punishment of exclusion from public held companies. On the other hand, the legislator remains silent regarding inclusion of arbitration term in the statute of commercial firms, however, there are no legal barriers to do so. Also the law of business (1932) in some of its articles, such as its article 108 states regarding LLCs: the relationships between the associates are functions of the statute.

On this basis, regarding the subject of inclusion of the arbitration term in the statute of commercial firms it can be stated:

According to the nature of statute and its acceptance in the relationships between the associates and stakeholders, the arbitration term is considered as a constituent of a collective agreement, and so it must be adhered to. Anticipating this term in the statute is a bilateral act as it is for direct contracts, and there is no reason to refuse it.

On this basis, if the statute of a commercial company maintains that the disputes between the associates must be resolved through arbitration, whether a specific person has been selected as the arbitrator or not, the parties will be committed to refer to arbitration for their disputes which they haven't been able to settle through negotiating.

The cases in which inclusion of the arbitration term in the statute of commercial firms is prohibited, include bankruptcy, which according to the article 496 of the civil procedure code (2001), cannot be referred to arbitration. This is because bankruptcy is associated to public order. On the other hand, regarding the cases of doubt and the associated reasons regarding the issue of inclusion of arbitration term in the statute of commercial firms it must be stated that certain lawyers believe that there are doubts regarding inclusion of arbitration term for certain disputes such as dissolution related ones. Because in terms of effects, a company's dissolution is similar to its bankruptcy and because of the reasons stated for bankruptcy, in case of dissolution also the case must be only referred to state courts.

\section{References}

Akhavan, M. (2012). The role of the Cooperative Chamber in resolving cooperative disputes, Rah-e Vakalt Quarterly, 8, 79-90. 
Ansari Moin, P. (2008). International Trade Law, Tehran, Mizan Publishing, first edition.

Ansari, Massoud and Mohammad Ali Taheri. (2005). Encyclopedia of Private Law, Tehran, Mihrab Fekr Publications, Ch1.

Dashti, M. R., \& Abbas, K. (2013). Comparative Study of Arbitration Contract, Journal of Comparative Law Studies, 4(1), 110-121.

Eskandari, A. M. (2005). A Study of the Complementary Role of Alternative Dispute Resolution Methods in Resolving Claims Related to Coercive Guarantee and Damages, Bar Association Journal, 191, 789-799.

Hassani, H. (2006). Commercial Law, Tehran, Mizan Publishing, Ch5.

Jafari, L., \& Mohammad, J. (2007). Legal Terminology, Tehran, Ganj-e-Danesh Publications, 17 th edition.

Katozian, N. (2012). General Rules of Contracts, 7th Edition, Publishing Joint Stock Company, Volume 3.

Kaviani, K. (2001). the Constitution and the condition of arbitration in contracts approved by the Islamic Consultative Assembly, Journal of Legal and Political Research, 5, 34-56.

Khodakhashi, A. (2013). Judicial Dimensions of Bankruptcy Lawsuits, Quarterly Journal of Legal Excellence, 7(3), 56-77.

Moein, M. (2003). Moein Culture, Tehran, Si Gol Publishing, first edition.

Moin, M. (2001). Farhang-e Farsi, Tehran, Amir Kabir Publications, 18th edition, second volume.

Moslehi, I., Hossein, Ali., \& Mohsen, S. (2006). Investigating the Process of Alternative Dispute Resolution, Journal of Comparative Law, 1, 126-144.

Pavic, V. (2010). Annulment of arbitral awards in international commercial Arbitration, investment and commercial Arbitration.

Sadr, A., \& Seyed, M. (1994). Civil and Commercial Procedure, Tehran, Majid Jihad and University Publishing Institute, Second Edition.

Salimi, M., Babak, K., \&Mehdi, Zare. (2017). The Legal Nature of the Arbitration Condition, Quarterly Journal of Private and Criminal Law Research, 33, 245-266.

Shams, A. (2009). Advanced Civil Procedure, Drake Publications, Fifteenth Edition, Volume Three.

Shirvi, A. (2014). International Commercial Arbitration, Samat Publications, third edition.

Zandi, M. (2014). Arbitration, Judicial Procedure of Tehran Courts of Appeal in Civil Matters, Fourth Edition, Jangal Publications. 